\title{
The effect of Zeranol implantation on thermoregulatory, hematological and physiological responses to heat stress in weaned lambs
}

\author{
S. LANDAU, Y. YEGANA *, D. WOLFENSON *, A. BEN-ASHER \\ Extension Service, Ministry of Agriculture, Yaakov 3, Rehovot 76262, Israel \\ * Department of Animal Science. The Hebrew University, \\ Faculty of Agriculture, Rehovot 76100, Israel
}

\begin{abstract}
Summary
A 33-day experiment was carried out to examine the effect of implanting $12 \mathrm{mg}$ Zeranol to weaned male lambs of the Assaf (East-friesian $\times$ Awassi) breed weighing $17.5 \mathrm{~kg}$, in normothermic conditions as well as during heat stress. Zeranol had no effect on weight gain, feed intake and feed efficiency, but the water intake and the ratio of water to concentrate intake were increased during the first 19 days post-implantation.
\end{abstract}

Half of the implanted and non-implanted lambs were submitted twice to a 9 hour heat stress. An average $0.63{ }^{\circ} \mathrm{C}$ increase in body-temperature was noted in the heat-stressed lambs. No differences were found in rectal temperature, ear temperature, or respiratory rate between implanted and non-implanted lambs. The plasma concentrations of glucose, urea, sodium, potassium, and plasma osmolality were not altered by the heat-stress or the zeranol implantation.

The heat-stressed lambs exhibited a marked eosinopenia and leucocytosis, which was more pronounced in the zeranol-implanted animals.

These results suggest that Zeranol is not effective in promoting growth of young weaned lambs, nor does it alleviate the stress of heat in these animals.

Key words : Heat-stress, Zeranol, lambs.

\section{Introduction}

In large regions of the Eastern basin of the Mediterranean, on the fringe of desertic areas, the transition periods between the dry and the rainy season (OctoberNovember) and reciprocal (April-May) are characterized by sudden increases in air temperatures, and concomitant decreases in relative humidity (typically : 33-39 ${ }^{\circ} \mathrm{C}, 20-25$ p. $100 \mathrm{RH}$, according to BoRSuT \& GAT, 1978). Therefore, winter-born and summerborn animals experience these short term but effective heat-stress, that can affect particularly the growth of weaned lambs of prolific breeds (E. EYAL, personal communication).

Steers implanted with $36 \mathrm{mg}$ Zeranol (R.G. BROWN, personal communication) or kids implanted with $12 \mathrm{mg}$ Zeranol (TAL-Or, LANDAU \& MoAv, 1984) exhibit a lower 
rectal temperature than non-implanted controls under normothermic conditions. Zeranol implants mitigated the effects of a harsh heat-stress in steers $\left(45^{\circ} \mathrm{C}, 60 \mathrm{p} .100 \mathrm{RH}\right)$ : the implanted steers reached a critical core-temperature of $41^{\circ} \mathrm{C}$ after a 10.2 hours exposure, whereas the controls reached it after 5.7 hours. In addition, the rise in serum glucose concentration of the implanted steers was very mild $(10 \mathrm{p} .100)$, as compared to a tremendous rise $(50$ p. 100) in the control steers (Sмiтн et al., 1976a). In contrast, other authors found that glycemia was increased in calves, 36 hours after Zeranol implantation and a decrease in eosinophile count was recorded, 24 hours after implantation (Kelley et al., 1982); eosinopenia is related to the reaction of mammals to stressors (DANTZER \& MORMEde, 1979).

Zeranol was found an effective growth-promoter for intact male lambs implanted at $30 \mathrm{~kg}$ body-weight (WILSON et al., 1972 ; LANDAU et al., 1981). To the best of our knowledge, its effect on the performance of younger lambs has not been reported, nor the possible interactions between Zeranol implantation and heat-stress in lambs.

This study was aimed at assessing the response of young weaned lambs to Zeranol implantation and its possible interaction with their reaction to heat-stress conditions.

\section{Material and methods}

Twelve two-month old intact male lambs of the Assaf (East-friesian $\times$ Awassi) breed were sorted into two groups, according to their body-weight (17.5 \pm 1.2 , Mean\pm SEM, $\mathrm{kg}$ ) and allocated to individual crates at the end of March. After a period of adaptation, six lambs were implanted with a $12 \mathrm{mg}$ Zeranol pellet (Ralgro, IMC Corporation, Terre-Haute, Indiana, U.S.A.) ; six lambs were left unimplanted and served as controls. They were self-fed a pelleted concentrate compounded with : 32.1 p. 100 corn, 33.4 p. 100 barley, 22 p. 100 soya-bean meal, 5 p. 100 wheat-bran, 3 p. 100 limestone, 1 p. 100 bentonite, 2.8 p. 100 salt-bentonite, 0.5 p. 100 ammonium chloride and 0.2 p. 100 of a mineral and vitamins mixture. Feed and water were available ad libitum. Lamb weight and individual intake of concentrate were recorded every 9-10 days whereas water intake was daily recorded.

On the fifth day post-implantation, half ot the crates were grouped and covered with polyethylene insulatory sheets. Six lambs ( 3 implanted and 3 controls) were radiant-heated during 9 hours, using $150 \mathrm{~W}$ infra-red lamps hanging $30 \mathrm{~cm}$ overhead; they were termed Ralgro Heated-RH, and Control Heated-CH. Six lambs (3 implanted and 3 controls) were left unheated and were termed Ralgro Control-RC, and Control Control-CC. A similar heating procedure was performed on day 17 th post-implantation.

Maximal and minimal air temperatures were daily recorded and measurements of relative humidity were obtained from the nearby meteorological station. Naturally occurring hot spells were noted on days 11, 19, 23 and 31 of the experiment.

Rectal temperatures (Tr) and ear temperatures (Te) were measured at a $\pm 0.05^{\circ} \mathrm{C}$ accuracy using thermistor probes (Model 46 TUC Tele-thermometer, YSI, Yellow Springs, Ohio, U.S.A.).

Respiratory rate $(R R)$ was evaluated by counting the flank beats. Blood samples were drawn from the jugular vein using EDTA vacutainers and kept on ice. After 
centrifugation at $5^{\circ} \mathrm{C}$, aliquots were taken for hematological examination and the plasma was stored at $-18{ }^{\circ} \mathrm{C}$ until analyzed. Hematological counts were performed as described by Yegana et al. (1983). Plasma glucose concentration was determined as described by Lerner \& Ben Yonah (1963) and urea nitrogen was determined according to Coulombe \& Favreau (1963). Plasma was examined for sodium and potassium by Flame-photometry (Evans electro-selenium, Halstead, England) after suitable dilution with bi-distilled water. Plasma osmolality was measured with a freezing point depression osmometer (Osmette Model 2007, Precision Systems Inc., Sudbury, MA, U.S.A.).

The analysis of body-weight gain, feed and water intake, and feed efficiency were made according to 2 experimental periods (days 1-19 and 20-33), since it has been shown that a maximal response to Zeranol in lambs is achieved during the first 3 weeks after implantation (LANDAU et al., 1981). All results were analyzed using a bi-factorial at random scheme of variance analysis, the first factor being Ralgro (R) or Control (C), and the second one, Heating (H) or Control (C) (SNedecor \& Cochran, 1968).

\section{Results}

\section{A. Climatic conditions}

Maximal and minimal temperatures during the experiment are shown in figure 1 ; relative humidity was in the ranges $17 \mathrm{p} .100$ (hot-spell) to $72 \mathrm{p} .100$ at 14.00 and 49 p. 100 to 99 p. 100 , at 20.00 . The air temperature in the heated and unheated cages at the beginning and the end of the first heating procedure were $15.5^{\circ} \mathrm{C}, 28^{\circ} \mathrm{C}$ and $14.3^{\circ} \mathrm{C}, 20.8^{\circ} \mathrm{C}$, respectively. During the second heating procedure, these values were $13.0^{\circ} \mathrm{C}, 34.8^{\circ} \mathrm{C}$ and $13.5^{\circ} \mathrm{C}, 21.2^{\circ} \mathrm{C}$, respectively. During the hot spells, air temperatures reached 33.5 ' $\mathrm{C}$ inside the shed.

\section{B. Growth-rate, feed and water consumption and feed efficiency}

No differences were found between treatments in body-weight gain (Table 1). The overall feed intake was similar in all groups during the experiment. Also, no significant differences in feed efficiency were recorded. Implanted lambs drank significantly more water than controls on days $1-19(+19.8 \mathrm{p} .100, \mathrm{P}<0.05)$, as shown in figure 2 . This difference was maximized on days 9-19, when the implanted lambs drank $3.23 \mathrm{l} / \mathrm{d}$, as compared with $2.38 \mathrm{l} / \mathrm{d}$ for the non-implanted ones $(+26.3 \mathrm{p} .100, \mathrm{P}<0.01)$. During days $1-19$, the ratio of water to concentrate intake was higher in the implanted lambs than in the non-implanted $(2.67$ vs. $2.20, \mathrm{P}<0.1)$. Water intake and the water-toconcentrate ratio were not significantly different between groups in the second part of the experimental period (days 20-31).

\section{Thermal responses to artificial heating}

A mild hyperthermia was noted in artificially-heated lambs $\left(0.78^{\circ} \mathrm{C}, \mathrm{P}<0.02\right.$ in procedure $1 ; 0,48{ }^{\circ} \mathrm{C}, \mathrm{P}<0.01$ in procedure 2 , average : $0.63^{\circ} \mathrm{C}$ ). Since the thermal 
responses to heat-stress were similar during the 2 heating procedures, only the first heating-procedure is reported in table 2. During heating, the increase of $\operatorname{Tr}$ was similar in the implanted and unimplanted lambs.

No differences were found between the ear temperatures of implanted and nonimplanted lambs, which suggests that Zeranol implants apparently did not enhance vaso-dilatory reactions to heat. In addition, similar patterns of change in respiratory rates were observed in the $\mathrm{RH}$ and $\mathrm{CH}$ lambs.

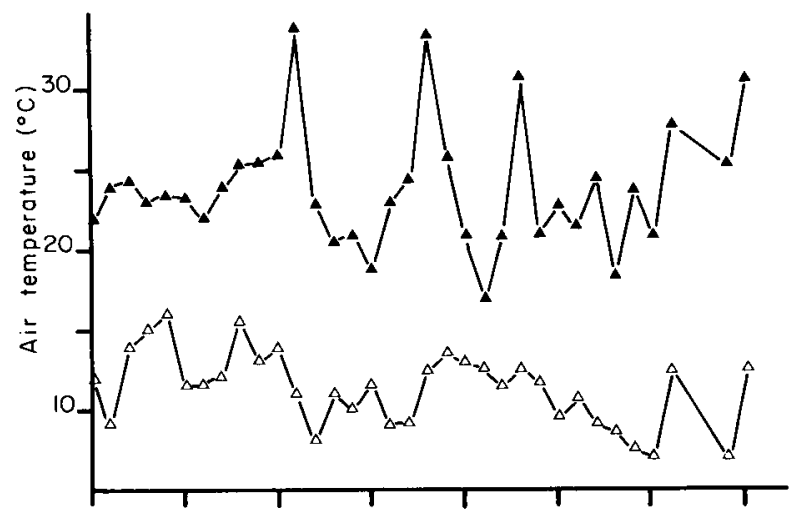

FiG. 1

Maximal (A) and minimal ( $\triangle$ ) air temperatures during the experiment (day $0=$ Zeranol implantation).

Températures maximale $(\mathbf{\Delta})$ et minimale $(\Delta)$ expérimentales (jour $0=$ Implantation au Zeranol).

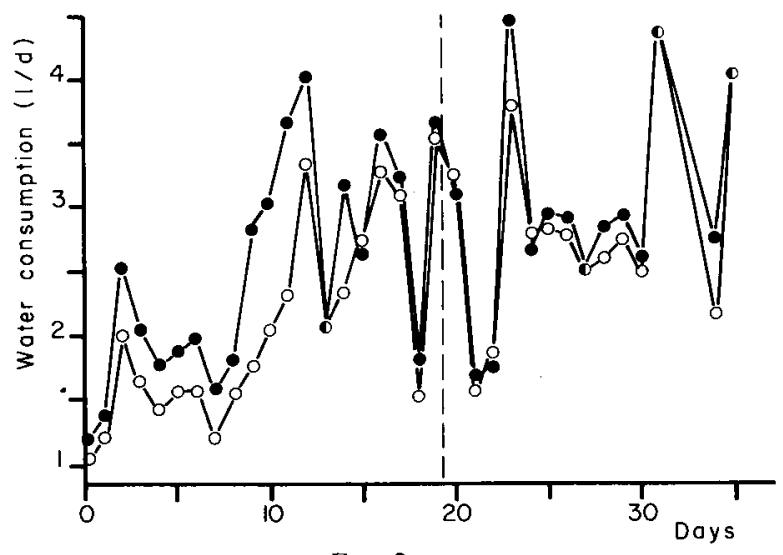

FIG. 2

Mean daily water intake of Zeranol-implanted $(n=6$, and non-implanted lambs $(n=6,0)$, during the experiment.

Consommation d'eau journalière d'agneaux implantés $(n=6$, ou non-implantés $(n=6,0)$ au Zeranol pendant la période expérimentale. 


\section{TABLE 1}

Body-weight gain, feed and water intakes, feed efficiency and the ratio of water to concentrate intake (RH-Ralgro Heated, RC-Ralgro Control, CH-Control Heated, CC-Control Control,

$n=3$ for each group), during the two experimental periods (days 1-19 and days 20-33).

Gain de poids, consommation de concentré et d'eau, et consommation d'eau rapportée à la consommation de concentré (RH-Ralgro Heated, RC-Ralgro Control, CH-Control Heated, CC-Control Control, $n=3$ pour chaque groupe), pendant les deux périodes expérimentales (jours 1-19 et 20-33).

\begin{tabular}{|c|c|c|c|c|c|}
\hline & $\begin{array}{l}\text { Body-weight } \\
\text { gain } \\
\text { (g/d) }\end{array}$ & $\begin{array}{l}\text { Feed Intake } \\
(\mathrm{g} / \mathrm{d})\end{array}$ & $\begin{array}{c}\text { Water intake } \\
(\mathrm{g} / \mathrm{d})\end{array}$ & $\begin{array}{c}\text { Feed/gain } \\
(\mathrm{Kg} / \mathrm{Kg})\end{array}$ & $\begin{array}{c}\text { Water/Feed } \\
(\mathrm{Kg} / \mathrm{Kg})\end{array}$ \\
\hline \multicolumn{6}{|l|}{ Days $1-19$} \\
\hline RH $\ldots \ldots$ & 290 & 922 & 2460 & 3.18 & 2.67 \\
\hline $\mathrm{RC} \ldots \ldots$ & 290 & 896 & 2400 & 3.09 & 2.68 \\
\hline $\mathrm{CH} \ldots \ldots \ldots$ & 317 & 968 & 2220 & 3.05 & 2.29 \\
\hline $\mathrm{CC}$ & 267 & 820 & 1730 & 3.07 & 2.11 \\
\hline SEM . . . . . . & 30 & 46 & 275 & 0.31 & 0.15 \\
\hline \multicolumn{6}{|l|}{ Effects } \\
\hline $\mathbf{R} \ldots \ldots \ldots$ & NS & NS & $p<0.01$ & NS & $\mathrm{p}<0.1$ \\
\hline$H \ldots \ldots$ & NS & NS & $p<0.10$ & NS & NS \\
\hline $\mathrm{R} \times \mathrm{H}$ & NS & NS & NS & NS & NS \\
\hline \multicolumn{6}{|l|}{ Days $20-33$} \\
\hline RH $\ldots \ldots$ & 331 & 1166 & 3760 & 3.52 & 3.22 \\
\hline$\ldots \ldots$ & 291 & 1074 & 3310 & 3.69 & 3.08 \\
\hline $\mathrm{CH} \ldots \ldots \ldots$ & 378 & 1134 & 3360 & 3.11 & 2.96 \\
\hline $\mathrm{CC}$ & 341 & 1072 & 2930 & 3.14 & 2.73 \\
\hline SEM . . . . . & 28 & 36 & 253 & 0.35 & 0.19 \\
\hline \multicolumn{6}{|l|}{ Effects } \\
\hline$\ldots \ldots$ & NS & NS & NS & NS & NS \\
\hline $\mathbf{H} \ldots \ldots \ldots$ & NS & NS & NS & NS & NS \\
\hline $\mathrm{R} \times \mathrm{H}$ & NS & NS & NS & NS & NS \\
\hline
\end{tabular}

D. Plasmatic concentrations of glucose, urea nitrogen and electrolytes

Glycemia was similar in all lambs, at all the sampling times during the heating procedures. During the second heating procedure a consistent tendency for a higher concentration of plasma urea nitrogen was noted in the heated lambs $(40 \mathrm{mg} / 100 \mathrm{ml}$, vs. $29.6 \mathrm{mg} / 100 \mathrm{ml})$, after 9 hours heating $(\mathrm{P}<0.1)$; this tendency was maintained 8 hours after the heating was terminated $(45.6 \mathrm{mg} / 100 \mathrm{ml}$, vs. $36.3 \mathrm{mg} / 100 \mathrm{ml}, \mathbf{P}<0.1)$. The average concentrations of $\mathrm{Na}$ and $\mathrm{K}$ in plasma were $127.5 \pm 1.8$ and $4.55 \pm 0.09$ (Mean $\pm \mathrm{SEM}, \mathrm{meq} / \mathrm{l}$ ) respectively, and the average osmolality was $285.6 \pm 2.5 \mathrm{mosm} /$ 1. No differences in these parameters were found between treatments at any of the sampling times. 
TABLE 2

Rectal temperature $\left({ }^{\circ} \mathrm{C}\right)$, before $(\operatorname{Tr} 0)$ and after 9 hours $(\operatorname{Tr} 9)$ heating, $\operatorname{Tr} 9-\operatorname{Tr} 0$ difference, ear temperature $\left(\mathrm{Te},{ }^{\circ} \mathrm{C}\right)$, and respiratory rate $\left(R R, m n^{-1}\right)$ during the first heating procedure (day 5 post-implantation).

Temperature rectale $\left({ }^{\circ} \mathrm{C}\right)$, avant ( $\left.\operatorname{Tr} 0\right)$ et après 9 heures d'exposition à la chaleur $(\operatorname{Tr} 9)$, différence $\operatorname{Tr} 9-\operatorname{Tr} 0$, température de l'oreille (Te) et fréquence respiratoire $\left(\mathrm{mn}^{-1}\right)$ pendant la première phase d'exposition à la chaleur ( $5^{\mathrm{e}}$ jour après l'implantation).

\begin{tabular}{|c|c|c|c|c|c|c|c|}
\hline & TR 0 & TR 9 & $\Delta \mathrm{TR}$ & TE 0 & TE 9 & RR 0 & RR 9 \\
\hline RH & 38.85 & 39.75 & 0.90 & 33.55 & 37.25 & 35 & 167 \\
\hline$\ldots \ldots \ldots \ldots$ & 38.70 & 38.80 & 0.10 & 33.43 & 33.50 & 36 & 48 \\
\hline$\ldots \ldots \ldots \ldots$ & 38.90 & 39.55 & 0.65 & 33.50 & 36.95 & 43 & 182 \\
\hline$\ldots \ldots \ldots \ldots$ & 38.90 & 38.95 & 0.05 & 33.72 & 33.70 & 53 & 52 \\
\hline SEM . & 0.26 & 0.16 & 0.16 & 0.36 & 0.51 & 10 & 17 \\
\hline \multicolumn{8}{|l|}{ Effects } \\
\hline $\mathbf{R}$ & NS & NS & NS & NS & NS & NS & NS \\
\hline $\mathrm{H}$ & NS & $\mathrm{p}<0.02$ & $p<0.05$ & NS & $\mathrm{p}<0.001$ & NS & $\mathrm{p}<0.01$ \\
\hline Interaction $\mathrm{R} \times \mathbf{H}$ & NS & NS & NS & NS & NS & NS & NS \\
\hline
\end{tabular}

TABLE 3

The number of circulating leucocytes $(L N, \times I 000 / \mathrm{ml})$ and their differential count $(\% L N)$ in the blood of the experimental lambs at sampling times during the first heating procedure. Concentration des leucocytes dans le sang $(L N, \times 1000 / \mathrm{ml})$ et leur répartition différentielle $(\% L N)$ à plusieurs prélèvements, pendant la première phase d'exposition à la chaleur.

\begin{tabular}{|c|c|c|c|c|c|c|c|}
\hline \multirow[b]{3}{*}{ Before Heating } & \multicolumn{4}{|c|}{ Treatment } & \multicolumn{3}{|c|}{ Effects } \\
\hline & RH & $\mathrm{RC}$ & $\mathrm{CH}$ & $\mathrm{CC}$ & $\mathbf{R}$ & $\mathbf{H}$ & $\mathrm{R} \times \mathrm{H}$ \\
\hline & & & & & & & \\
\hline Leucocyte number (LN) & 8.2 & 6.5 & 7.5 & 6.0 & NS & NS & NS \\
\hline Lymphocytes (\% LN) & 43.0 & 38.0 & 41.5 & 52.0 & NS & NS & NS \\
\hline Neutrophiles $(\% \mathrm{LN})$ & 48.5 & 52.5 & 53.0 & 38.5 & NS & NS & NS \\
\hline Monocytes (\% LN) . & 7.0 & 2.5 & 2.5 & 5.5 & NS & NS & $\mathrm{p}<0.1$ \\
\hline Eosinophiles $(\% \mathrm{LN})$ & 1.5 & 7.0 & 3.0 & 4.0 & NS & NS & NS \\
\hline \multicolumn{8}{|l|}{ After $4 \mathrm{Hr}$ Heating } \\
\hline Leucocyte number (LN) . . & 9.1 & 6.6 & 7.9 & 5.8 & NS & $\mathrm{p}<0.01$ & NS \\
\hline Lymphocytes $(\% \mathrm{LN})$ & 44.0 & 41.5 & 44.5 & 40.5 & NS & NS & NS \\
\hline Neutrophiles $(\%, \mathrm{LN})$ & 52.5 & 49.5 & 50.0 & 55.0 & NS & NS & NS \\
\hline Monocytes ( $\%$ LN) & 3.5 & 5.0 & 4.0 & 3.5 & NS & NS & NS \\
\hline Eosinophiles $(\% \mathrm{LN})$ & 0.0 & 4.0 & 1.5 & 1.0 & NS & $\mathrm{p}<0.05$ & $p<0.05$ \\
\hline \multicolumn{8}{|l|}{ Alter $9 \mathrm{Hr}$ Heating } \\
\hline Leucocyte number (LN) & 13.9 & 10.9 & 9.7 & 8.1 & NS & NS & NS \\
\hline Lymphocytes (\% LN) & 40.0 & 31.5 & 45.0 & 59.5 & $\mathrm{p}<0.1$ & NS & NS \\
\hline Neutrophiles $(\%$ LN) & 56.0 & 61.5 & 50.0 & 35.0 & $\mathrm{p}<0.1$ & NS & NS \\
\hline Monocytes (\% LN) & 4.0 & 4.0 & 3.5 & 4.5 & NS & NS & NS \\
\hline Eosinophiles $(\% \mathrm{LN})$ & 0.5 & 3.0 & 1.5 & 1.5 & NS & NS & NS \\
\hline
\end{tabular}




\section{E. Hematological counts}

Heating had an exacerbating effect on the count of circulating leucocytes after 4 hours of the first heating procedure $(P<0.01)$ whereas Zeranol had no significant effect (Table 3). Despite the fact that the first heating procedure was performed only 5 days post-implantation, all the effects can be related to treatments and are not aftereffects of the implanting procedure, since no significant differences were present prior to heating. Also, the heated lambs had a lower eosinophile percentage, 4 hours after the first heating procedure was initiated $(\mathrm{P}<0.05)$. A significant implanting by heat stress interaction on this parameter was also found $(\mathrm{P}<0.05)$. After 9 hours of the first heating procedure, neutrophile percentage was higher in the implanted lambs than in the controls $(\mathrm{P}<0.1)$. The effects of the treatments were similar during the second heating procedure, therefore, only heat procedure 1 is presented in Table 3 : during the second heating procedure, the heated lambs had lower eosinophile $(P<0.05)$ and neutrophile percentages $(P<0.05)$ than their unheated counterparts.

\section{Discussion}

The thermal responses, i.e. the vasodilatory reaction to heat-stress, which was assessed by measuring the increase in ear temperature (BIANCA, 1968), the hyperthermia, and the change of the respiratory rhythm, were similar in the Zeranol implanted and non-implanted lambs.

Glycemia and fluctuations in the blood formula are widely used as indirect indicators of the adrenal cortex activation which occurs as a short-term reaction to environmental stressors (DANTZER \& MORMEDE, 1979). The eosinophile percentage of heat-stressed calves was reduced to half of the control level, although this trend was not statistically significant (KeLley et al., 1982). In another study, steers implanted with Zeranol and exposed to a cold stress exhibited such a decrease, which shows that implantation did not counteract the effect of stress on their hematological values (Kelley et al., 1981). In the present study as well, a depressed eosinophile percentage was noted in the heated lambs. The similar concentration of glucose in plasma, and the decrease in eosinophile percentage found in the lambs of both RH and RC groups, lead to the conclusion that implanting Zeranol to these weaned lambs did not alleviate the response to stressors (experimental stress or heat stress).

However, the usual metabolic changes, which are generally associated with Zeranol implantation, i.e., a decrease in blood urea nitrogen. indicative of a better nitrogen retention, and the growth response, were not observed in this study, which differs from results obtained in older lambs of the same breed (LANDAu et al., 1981). It may be suggested, therefore, that the effect of Zeranol on growth, as well as its role in the reaction of lambs to stress could be age-dependent.

A possible clue for the discrepancy between the present results and the former report that Zeranol-implanted steers were more resistant to heat-stress (SMITH et al., 1976a) could be the extent of fat depots in the animals : it is known that the Zeranol activity is associated with an increase in growth-hormone concentration, which itself is efficient as a growth-promoter via its lipolytic effect (HeITzman, 1979). 
The increased water consumption by the Zeranol implanted lambs in this study could be of beneficial value during a harsh heat-stress when water-turnover is markedly enhanced by respiratory and cutaneous evaporation. This finding corresponds well with the improved resistance of Zeranol implanted steers (SMith et al., 1976a). Chemineau \& Ravault (1984) showed significant positive correlations between rectal temperatures and the concentration of prolactin in blood plasma of "Creole goats is involved in hydric and mineral adaptation of animals to harsh environments (BURSTYN, 1978) and Zeranol implantation increases prolactin concentration and rate of clearance (Sмiтн et al., 1976b), it seems possible that this hormone has an important role in the water intake changes reported in our study.

\title{
V. Conclusions
}

Implanting $12 \mathrm{mg}$ Zeranol to weaned lambs weighing $17.5 \mathrm{~kg}$ did not improve growth-performance nor did it alleviate the effect of heat-stress on these lambs.

The implanted lambs drank significantly more water, on days 1-19 after implantation ; this increase in water intake was independent from feed intake, and could be of value to thermoregulation under heat-stress conditions more severe than was described in the present experiment.

Received on October 1986.

Accepted on December 1986.

\author{
Résumé \\ Effet de l'implantation de Zeranol sur les réponses thermiques, \\ hématologiques et physiologiques à un stress de chaleur \\ chez des agneaux sevrés
}

Une étude d'une durée de 33 jours a été menée afin d'examiner l'effet de l'implantation de 12 mg de Zeranol sur des agneaux de $17,5 \mathrm{~kg}$ de poids vif, sevrés et non-castrés de race Assaf (Frisonne de l'Est $\times$ Awassi), sous condition normothermique, ou pendant un stress de chaleur. Le Zeranol n'a eu aucun effet sur le gain de poids, la consommation d'aliment, et l'indice de consommation mais un effet positif a été noté sur la consommation d'eau et le quotient de cette dernière rapporté à la consommation d'aliment, pendant les 19 jours après l'implantation.

La moitié des agneaux implantés et non-implantés ont été soumis à un stress de chaleur de 9 heures. Chez ces agneaux, une hyperthermie moyenne de $0,63{ }^{\circ} \mathrm{C}$ a été notée. On n'a relevé aucune différence de température rectale, de température de l'oreille et du rythme respiratoire entre les agneaux implantés et ceux non-implantés. De même, les concentrations en glucose, urée, sodium, potassium, et l'osmolalité plasmatique n'ont pas été affectées par le stress de chaleur ou l'implantation de Zeranol.

Chez les agneaux soumis à un stress de chaleur, on a noté une éosinopénie et une leucocytose marquées, particulièrement prononcées chez les animaux implantés.

Ces résultats suggèrent que le Zeranol n'est pas efficace comme facteur de croissance chez de jeunes agneaux après sevrage et qu'il ne permet pas de réduire l'effet du stress de chaleur chez ces animaux.

Mots clés : Stress de chaleur, Zeranol, agneaux. 


\section{References}

Borsut Z., Gat Z., 1978. Preliminary survey on the Sharav events in Israel, pp. 15-22. Publication of the Meteorological Services, Bet-Dagan, Israel.

Burstyn P.G.R., 1978. Sodium and water metabolism under the influence of prolactin, aldosterone and anti-diuretic hormone. J. Physiol., 275, 39-50.

Chemineau P., Ravault J.-P., 1984. Variations horaires de la température rectale et de la prolactinémie chez le "Cabrit créole" maintenu à l'extérieur en milieu tropical. Reprod. Nutr. Develop., 24, 71-80.

Coulombe J.T., Favreau L., 1963. A new simple semimicro method for colorimetric determination of urea. Clin. chem., 9, 102-107.

Dantzer R., Mormede P., 1979. Physiopathologie de la réaction aux agressions, pp. 29-75, in "Le stress en élevage intensif "INRA et Masson (Paris) ed.

Heitzman R.J., 1979. Efficacy and mechanisms of action of anabolic agents as growth-promoters in Farm animals. J. Steroid Bioch., 11, 927-930.

Kelley K.W., Greenfield R.E., O'Connor M.T., Gaskins C.T., 1981. Acute cold stress in Zeranol-implanted steers. J. Anim. Sci., 53 (suppl.), 184 (Abstr.).

Kelley K.W., Osborne C.A., Evermann J.F., Parish S.M., Gaskins C.T., 1982. Effects of chronic heat and cold stressors on plasma immunoglobulin and mitogen-induced blastogenesis in calves. J. Dairy Sci., 65, 1514-1528.

Landau S., Eisner U., Pompanel D., Leitner G., Grinberg J., 1981. The effect of Ralgro implants on the growth performance of lambs of two breeds. under Israeli managerial conditions. Hassade, 61, 485-487 (in Hebrew).

Lerner H.S., Ben Yonah S., 1963. Routine determination of blood glucose with glucose oxidase. Bull. Res. Counc. Israel, 10, 188.

Smith V.G., Brown R.G., Hacker R.R., Alhassan W.S., 1976a. Effects of Ralgro on stress response in steers. J. Anim. Sci., 43, 305 (Abstr.).

Smith V.G., Hacker R.R., Brown R.G., 1976b. Effect of temperature on serum prolactin in steers. J. Anim. Sci., 43, 305 (Abstr.).

Snedecor G.W., Cochran W.G., 1968. Statistical methods. 6th ed., pp. 336-338, The Iowa Univ. Press. (Ames, Iowa, U.S.A.).

Tal-Or R., Landau S., Moav O., 1985. The effect of implanting Ralgro to intact male Saanen kids on their development and growth-performance. Hassade, 65, 2293-2296 (in Hebrew).

Wilson L.L., Varela-Alyarez H., Rugh M.C., Borger M.L., 1972. Growth and carcass characters of rams, cryptorchids, wethers and ewes implanted subcutaneously with Zeranol. $J$. Anim. Sci., 34, 336-345.

Yegana Y., Hod I., Orna Livne, Herz A.. 1983. Changing pattern of the serum proteins in asymptomatic sheep treated with cyclophosphamide for chemical shearing. Br. Vet. J., 139, 415-422. 